\title{
Kepastian Hukum Apotek Rakyat Dan Pekerjaan Kefarmasian
}

\author{
Anggi Restiasari, R. Ismadi S. Bekti, dan Ahmad Gozali \\ anggi_60001@yahoo.com \\ Magister Hukum Kesehatan \\ Universitas Katolik Soegijapranata Semarang
}

\begin{abstract}
ABSTRAK
Apotek merupakan tempat dilakukannya pekerjaan kefarmasian, penyaluran sediaan farmasi dan perbekalan kesehatan lainnya kepada masyarakat. Pekerjaan kefarmasiaan meliputi pembuatan termasuk pengendalian mutu sediaan farmasi, pengamanan, pengadaan, penyimpanan dan pendistribusian obat, pelayanan obat atas resep dokter (meliputi peracikan, pelayanan obat keras, psikotropika dan narkotika, sampai pemberian etiket dan label), pelayanan informasi obat serta pengembangan obat, bahan obat dan obat tradisional. Pekerjaan kefarmasian di apotek harus dilakukan oleh tenaga kesehatan yang mempunyai keahlian dan kewenangan sesuai dengan ketentuan peraturan perundang-undangan. Didalam pekerjaan kefarmasian di apotek, peranan apoteker menjadi perhatian utama karena apoteker merupakan tenaga kefarmasian yang mempunyai keahlian dan wewenang sebagai penanggung jawab dalam pekerjaan kefarmasian di apotek.

Berbeda halnya dengan Apotek Rakyat, Apotek Rakyat menurut Peraturan Menteri Kesehatan No. 284/MENKES/PER/III/2007 adalah sarana kesehatan tempat dilaksanakannya pelayanan kefarmasian dimana dilakukannya penyerahan obat dan perbekalan kesehatan dan tidak melakukan peracikan serta tidak boleh menyimpan dan menyerahkan narkotika dan psikotropika. Sehubungan terdapatnya beberapa ketentuan Apotek Rakyat berdasarkan Peraturan Menteri Kesehatan No. 284/MENKES/PER/III/2007 yang bertentangan dan tidak sesuai dengan ketentuan apotek berdasarkan peraturan perundang-undangan yang berlaku, maka pada tesis ini akan dibahas mengenai hubungan antara kepastian hukum Apotek Rakyat dengan Pekerjaan Kefarmasian.

Kepastian hukum tercapai apabila hukum tersebut didalamnya tidak terdapat keteranganketerangan yang bertentangan dan tidak terdapat istilah-istilah yang dapat ditafsirkan secara berlainan. Hukum yang berhasil ialah yang dapat menjamin banyak kepastian hukum dalam hubungan-hubungan kemasyarakatan, sehingga dapat mewujudkan keadilan dan ketertiban bagi para pihak yang berkepentingan (masyarakat dan pemerintah).

Berdasarkan analisis hubungan antara kepastian hukum Apotek Rakyat dengan Pekerjaan Kefarmasian, maka dapat ditarik kesimpulan bahwa ketentuan mengenai Apotek Rakyat berdasarkan Peraturan Menteri Kesehatan No. 284/MENKES/PER/III/2007 tidak memberikan kepastian hukum bagi apoteker dalam melaksanakan pekerjaan kefarmasian di Apotek Rakyat tersebut karena Peraturan Menteri Kesehatan No. 284/MENKES/PER/III/2007 tidak dapat memberikan perlindungan hukum, keadilan dan ketertiban bagi subjek hukum, yang dalam hal ini adalah masyarakat, baik masyarakat umum maupun masyarakat profesi (apoteker) atas pekerjaan kefarmasian. Sehingga, Peraturan Menteri Kesehatan No. 284/MENKES/PER/III/2007 harus dicabut, selanjutnya hanya mengacu pada ketentuan apotek sesuai dengan peraturan perundang-undangan yang berlaku.
\end{abstract}

Kata Kunci: Apotek, Apotek Rakyat, Apoteker, Pekerjaan Kefarmasian, Kepastian Hukum. 


\section{PENDAHULUAN}

Obat merupakan salah satu komponen yang tak tergantikan serta sangat menunjang dalam rangka upaya pembangunan dan pelayanan kesehatan yang baik. Obat dan perbekalan kesehatan adalah kebutuhan dasar manusia yang berfungsi sosial, sehingga tidak boleh diperlakukan sebagai komoditas ekonomi semata, juga tidak dipromosikan secara berlebihan dan menyesatkan. Akses terhadap obat terutama obat essensial merupakan salah satu hak azasi manusia. Disamping itu, Pemerintah dan sarana pelayanan kesehatan bertanggung jawab untuk menjamin agar pasien mendapat pengobatan yang rasional.

Kebijakan pemerintah dalam meningkatkan akses obat diselenggarakan melalui beberapa peraturan yaitu Peraturan Pemerintah, Program Indonesia Sehat 2010, Sistem Kesehatan Nasional (SKN) dan Kebijakan Obat Nasional (KONAS). Peraturan tersebut memberikan landasan, arah dan pedoman penyelenggaraan pembangunan kesehatan bagi seluruh penyelenggara kesehatan baik pemerintah, masyarakat, dunia usaha dan pihak lain yang terkait. Salah satu subsistem dalam Sistem Kesehatan Nasional (SKN) adalah obat dan perbekalan kesehatan. Dalam subsistem tersebut penekanan diberikan pada ketersediaan obat, pemerataan termasuk keterjangkauan dan jaminan mutu obat. Kebijakan obat nasional adalah dokumen kebijakan pelaksanaan program dibidang obat, sebagai penjabaran dari subsistem bidang obat dan perbekalan kesehatan dalam Sistem Kesehatan Nasional (SKN).

Semua obat yang beredar harus dijamin keamanan, khasiat dan mutunya agar benarbenar memberikan manfaat bagi kesehatan dan kesejahteraan masyarakat serta tidak merugikan masyarakat. Keterjangkauan dan penggunaan obat yang rasional merupakan bagian dan tujuan yang harus dicapai.

Salah satu tempat distribusi atau beredarnya obat-obatan serta perbekalan kesehatan masyarakat adalah apotek. Menurut Peraturan Pemerintah Nomor 51 Tahun 2009 tentang Pekerjaan Kefarmasian, apotek adalah sarana pelayanan kefarmasian tempat dilakukan praktek kefarmasian oleh apoteker. Praktek/pekerjaan kefarmasian yang dimaksud adalah pembuatan termasuk pengendalian mutu sediaan farmasi, pengamanan, pengadaan, penyimpanan dan pendistribusi atau penyaluran obat, pengelolaan obat, pelayanan obat atas resep dokter, pelayanan informasi obat serta pengembangan obat, bahan obat dan obat tradisional. Menurut Undang-Undang Kesehatan No. 36 Tahun 2009 pasal 108, pekerjaan kefarmasian tersebut harus dilakukan oleh tenaga kesehatan yang mempunyai keahlian dan kewenangan sesuai dengan peraturan perundang-undangan. Yang dimaksud dengan "tenaga kesehatan" dalam ketentuan ini adalah tenaga kefarmasian sesuai dengan keahlian dan kewenangannya. Dalam hal ini yang dimaksud penulis adalah apoteker. Pada Peraturan Pemerintah Nomor 51 Tahun 2009 pasal 24 dinyatakan bahwa dalam melakukan pekerjaan kefarmasian di apotek, apoteker dapat:

“a. mengangkat seorang Apoteker pendamping yang memiliki SIPA;

b. mengganti obat merk dagang dengan obat generik yang sama komponen aktifnya atau obat merk dagang lain atas persetujuan dokter dan/atau pasien;

c. menyerahkan obat keras, narkotika dan psikotropika kepada masyarakat atas resep dari dokter sesuai dengan ketentuan peraturan perundang-undangan."

Selain itu, apotek merupakan sarana informasi obat kepada masyarakat dan tenaga kesehatan lainnya. ${ }^{1}$ Apoteker harus memberikan konseling mengenai sediaan farmasi, pengobatan dan perbekalan kesehatan lainnya sehingga dapat memperbaiki kualitas hidup pasien atau yang bersangkutan terhindar dari bahaya penyalahgunaan sediaan farmasi atau

1 Muhamad Firmansyah, Tata Cara Mengurus Perizinan Usaha Farmasi \& Kesehatan, Cetakan pertama, Visimedia, Jakarta, Tahun 2009, hlm. 27. 
perbekalan kesehatan lainnya. ${ }^{2}$ Oleh karena itu, sesuai dengan Peraturan Pemerintah Nomor 51 Tahun 2009 pasal 54, Apoteker harus melaksanakan praktik kefarmasian di 1 (satu) apotek, puskesmas atau instalasi farmasi rumah sakit saja, sehingga pemberian informasi obat kepada masyarakat akan berjalan secara optimal.

Berbeda dengan apotek pada umumnya, apotek rakyat yang diatur dalam Peraturan Menteri Kesehatan No. 284 Tahun 2007 merupakan sarana kesehatan tempat dilaksanakannya pelayanan kefarmasian dimana dilakukan penyerahan obat dan perbekalan kesehatan, dan tidak melakukan peracikan, dilarang menyediakan Narkotika dan Psikotropika, serta dilarang menyerahkan obat dalam jumlah besar. Hal ini menyebabkan apotek bukan lagi sebagai tempat dimana masyarakat dapat memperoleh obat apapun yang dibutuhkannya. Selain itu, didalam ketentuan apotek rakyat, seorang apoteker bertanggungjawab terhadap 4 (empat) sarana apotek karena apotek rakyat dapat merupakan satu atau gabungan (paling banyak empat) pedagang eceran obat. Dalam hal ini berarti pelayanan yang diberikan apoteker tidak bisa optimal karena dalam waktu bersamaan tidak mungkin apoteker memberikan pelayanan pada tempat yang berbeda, berarti fungsi pelayanan apotek sebagai sarana informasi obat kepada masyarakat tidak tercapai dan fungsi pengawasan sebagaimana misi dari apotek rakyat yaitu melindungi masyarakat dari penggunaan obat-obat palsu, obat kadaluwarsa, obat yang tidak jelas asalusulnya, mencegah penyalahgunaan obat, dan menertibkan peredaran obat di sentra perdagangan atau di pasaran akan sulit untuk dicapai. ${ }^{3}$

Pembentukan apotek rakyat melalui Peraturan Menteri Kesehatan No. 284 Tahun 2007 tersebut dilatarbelakangi oleh maraknya peredaran obat-obat palsu dan ilegal, obat kadaluarsa, obat keras yang dijual tanpa resep dokter di daerah Pasar Pramuka. ${ }^{4}$ Praktek "ilegal" bertahuntahun ini seperti tak tersentuh dan sulit sekali diberantas. Badan Pengawas Obat dan Makanan (BPOM) melansir, sejak 1999 hingga 2006 jumlah obat palsu yang beredar di pasaran Indonesia mencapai 81 merek, mulai dari obat hipertensi, diabetes, antibiotik, hingga obat sakit kepala. Badan Kesehatan Dunia (WHO) juga melansir, jumlah kerugian akibat obat palsu di Indonesia mencapai Rp 3 triliun per tahun. ${ }^{5}$ Menurut penulis, seharusnya pihak pemerintah meningkatkan pengawasan terhadap peredaran sediaan farmasi dengan pemberian efek jera bagi pelanggar yang melakukan, sehingga tidak mengorbankan keprofesian apoteker melalui pembentukan Apotek Rakyat dalam upaya menghadapi masalah tersebut.

Dari uraian diatas, dapat dilihat bahwa misi dari pembentukan Apotek Rakyat melalui Peraturan Menteri Kesehatan No. 284 Tahun 2007 itu untuk melindungi masyarakat dari peredaran obat yang palsu dan tidak bermutu. Namun pada beberapa pasalnya bertentangan dengan ketentuan apotek berdasarkan peraturan perundang-undangan yang berlaku. Sehingga terdapat pihak yang dirugikan diantaranya adalah apoteker yang mempunyai keahlian dan kewenangan atas pekerjaan kefarmasian di apotek karena menyebabkan tidak adanya kepastian hukum dan perlindungan hukum terhadap keprofesiannya atas pekerjaan kefarmasian. Selain itu, ditemukan ketidaksesuaian yang melanggar hak masyarakat. Idealnya yang membutuhkan apotek rakyat adalah rakyat biasa dalam kategori pasien yang membutuhkan obat murah, tetapi kenyataannya konsumen yang berbelanja di apotek rakyat adalah para pedagang obat, para dokter, para pemilik klinik. Hal ini terbukti berdasarkan kutipan penulis dari pengalaman seorang

\footnotetext{
2 Yustina Sri Hartini, Apotek Ulasan Beserta Naskah Peraturan Perundang-undangan Terkait Apotek Termasuk Naskah dan Ulasan Permenkes Tentang Apotek Rakyat, Edisi Revisi, Cetakan ketiga, Universitas Sanata Dharma, Yogyakarta, Tahun 2010, hlm. 60.

3 Anonim, Pemerintah Resmikan Program Apotek Rakyat, Harian Umum Kompas, Jakarta, 4 April 2007.

4 Yustina Sri Hartini, Apotek Ulasan Beserta Naskah Peraturan Perundang-undangan Terkait Apotek Termasuk Naskah dan Ulasan Permenkes Tentang Apotek Rakyat, Edisi Revisi, Cetakan ketiga, Universitas Sanata Dharma, Yogyakarta, Tahun 2010, hlm. 91-92.

${ }^{5}$ Rizki Prasa, Apotek Rakyat dan Apotek Waralaba, http://prastza-dubidudam.blogspot.com, Surakarta, 15 Oktober 2009.
} 
konsumen yang menyerahkan resep tidak dilayani karena hanya berjumlah kurang lebih 1.5 strip (15 tablet). Konsumen hanya akan dilayani apabila membeli obat dengan jumlah minimal 1 box. ${ }^{6}$ Sehingga apotek rakyat bertentangan dengan fungsi apotek sebagai sarana pelayanan kefarmasian kepada masyarakat.

Berdasarkan uraian diatas jelas terlihat adanya ketidaksesuaian mengenai ketentuan apotek rakyat dengan ketentuan apotek pada umumnya sesuai dengan peraturan perundangundangan sehingga menyebabkan tidak adanya kepastian hukum bagi pihak yang terkait yaitu diantaranya bagi apoteker. Untuk membantu menguraikan permasalahan tersebut, maka penulis menuangkan judul suatu tesis sebagai berikut: "KEPASTIAN HUKUM APOTEK RAKYAT DAN PEKERJAAN KEFARMASIAN".

Penelitian tesis ini menggunakan metode penelitian dengan pendekatan yuridis normatif dengan cara berpikir deduktif dan spesifikasi penelitian deskriptif analitis untuk mencari sebab akibat dari permasalahan yang terdapat pada perumusan masalah dan menguraikannya secara konsisten, sistematis dan logis sesuai dengan perumusan masalah yang menjadi fokus dalam penelitian ini, yaitu hubungan antara Kepastian Hukum Apotek Rakyat dengan Pekerjaan Kefarmasian.

\section{PEMBAHASAN}

Sesuai dengan tujuan dari Peraturan Pemerintah No. 51 Tahun 2009 tentang Pekerjaan Kefarmasian yaitu memberikan perlindungan kepada pasien dan masyarakat dalam memperoleh dan menetapkan sediaan farmasi dan jasa kefarmasian, mempertahankan dan meningkatkan mutu penyelenggaraan pekerjaan kefarmasian, serta untuk memberikan kepastian hukum bagi pasien, masyarakat dan tenaga kefarmasian. Maka perlu pengaturan yang dapat memberikan kepastian hukum mengenai pekerjaan kefarmasian di Apotek Rakyat. Oleh karena itu, penulis akan mengkaji isi naskah dalam peraturan Apotek Rakyat dan dihubungkan dengan ketentuan pekerjaan kefarmasian di apotek pada umumnya sesuai peraturan perundang-undangan agar dapat diketahui apakah ketentuan Apotek Rakyat menurut Peraturan Menteri Kesehatan No. 284/MENKES/PER/III/2007 memberikan kepastian hukum terhadap apoteker atas pekerjaan kefarmasian.

Menurut penulis, isi naskah dalam peraturan Apotek Rakyat maknanya terkesan bias dan banyak sekali menyimpang dari peraturan perundang-undangan yang menyangkut apotek, pekerjaan kefarmasian, Undang-Undang Kesehatan No. 36 Tahun 2009, Undang-Undang No. 5 Tahun 1997 tentang Psikotropika, serta Undang-Undang No. 35 Tahun 2009 tentang Narkotika. Permasalahan tersebut antara lain:

1. Apotek Rakyat dilarang meracik obat sesuai dinyatakan pada Pasal 5 ayat 2. Meracik obat merupakan salah satu pekerjaan kefarmasian yang merupakan wewenang apoteker. Sehingga pasal tersebut bertentangan dengan:

a. Undang-Undang Kesehatan No. 36 Tahun 2009 Pasal 108 ayat 1 disebutkan bahwa pekerjaan kefarmasiaan meliputi pembuatan termasuk pengendalian mutu sediaan farmasi, pengamanan, pengadaan, penyimpanan dan pendistribusian obat, pelayanan obat atas resep dokter, pelayanan informasi obat serta pengembangan obat, bahan obat dan obat tradisional. Meracik obat merupakan salah satu bentuk pelayanan obat atas resep dokter. Pekerjaan kefarmasian tersebut harus dilakukan oleh tenaga kesehatan yang mempunyai keahlian dan kewenangan sesuai dengan ketentuan peraturan perundangundangan. Dalam hal ini tenaga kesehatan yang berwenang penuh atas pekerjaan kefarmasian adalah apoteker. Kemudian dalam Pasal 198 dinyatakan bahwa:

${ }^{6}$ Rizki Prasa, Apotek Rakyat dan Apotek Waralaba, http://prastza-dubidudam.blogspot.com, Surakarta, 15 Oktober 2009. 
"Setiap orang yang tidak memiliki keahlian dan kewenangan untuk melakukan praktik kefarmasian sebagaimana dimaksud dalam Pasal 108 dipidana dengan pidana denda paling banyak Rp100.000.000,00 (seratus juta rupiah)."

b. Peraturan Pemerintah No. 51 Tahun 2009 tentang Pekerjaan Kefarmasian Pasal 1 ayat 1 disebutkan bahwa: "Pekerjaan Kefarmasian adalah pembuatan termasuk pengendalian mutu sediaan farmasi, pengamanan, pengadaan, penyimpanan dan pendistribusi atau penyaluran obat, pengelolaan obat, pelayanan obat atas resep dokter, pelayanan informasi obat, serta pengembangan obat, bahan obat dan obat tradisional." Meracik obat merupakan salah satu bentuk pelayanan obat atas resep dokter. Selanjutnya, pasal 51 ayat 1 menjelaskan bahwa pelayanan kefarmasian di apotek hanya dapat dilakukan oleh apoteker. Jadi, meracik obat adalah wewenangnya apoteker.

C. Peraturan Menteri Kesehatan No. 922/MENKES/PER/1993 tentang Ketentuan dan Tata Cara Pemberian Izin Apotek Pasal 10 (a) Pengelolaan Apotek meliputi pembuatan, pengolahan, peracikan, pengubahan bentuk, pencampuran, penyimpanan, dan penyerahan obat atau bahan obat.

d. Peraturan Pemerintah No. 41 Tahun 1990 tentang Masa Bakti dan Izin Kerja Apoteker Pasal 1 ayat 2 yang dimaksud dengan pekerjaan kefarmasian adalah pembuatan, pengolahan, peracikan, pengubahan bentuk, pencampuran, penyimpanan, dan penyerahan perbekalan farmasi.

e. Keputusan Menteri Kesehatan No. 1027/MENKES/SK/IX/2004 tentang Standar Pelayanan Kefarmasian di Apotek Bab II mengenai pelayanan sediaan farmasi (dalam hal ini sediaan farmasi termasuk obat) meliputi perencanaan, pengadaan, penyimpanan, dan pelayanan. Pada Bab III tentang Pelayanan Resep termasuk didalamnya adalah peracikan yaitu merupakan kegiatan menyiapkan, menimbang, mencampur, mengemas, dan memberikan etiket pada wadah.

f. Reglement D.V.G (ST.1882 No. 97) Pasal 56 yang menyebutkan bahwa yang berhak menjalankan peracikan obat hanyalah Apoteker dan Asisten Apoteker dengan persyaratan tertentu.

Jika melihat peraturan perundang-undangan diatas, maka pada peraturan mengenai Apotek Rakyat dapat dikatakan bahwa wewenang apoteker di dalam Apotek Rakyat atas pekerjaan kefarmasian dibatasi atau dilanggar karena tidak boleh melakukan peracikan obat yang merupakan salah satu pekerjaan kefarmasian dimana profesi lain tidak dapat melakukannya.

2. Apotek Rakyat dilarang menyimpan dan menyerahkan narkotika dan psikotropika pada Pasal 5 ayat 2, yang artinya peraturan ini membatasi peran dan wewenang apoteker atas pekerjaan kefarmasian yang salah satunya wewenang untuk menyerahkan psikotropika dan narkotika. Sehingga pasal tersebut bertentangan dengan:

a. Undang-Undang Kesehatan No. 36 Tahun 2009 Pasal 108 ayat 1 disebutkan bahwa pekerjaan kefarmasiaan meliputi pembuatan termasuk pengendalian mutu sediaan farmasi, pengamanan, pengadaan, penyimpanan dan pendistribusian obat, pelayanan obat atas resep dokter, pelayanan informasi obat serta pengembangan obat, bahan obat dan obat tradisional. Menyimpan dan menyerahkan narkotika dan psikotropika merupakan salah satu bentuk pelayanan obat atas resep dokter sesuai dengan Pasal 102 ayat 1, "Penggunaan sediaan farmasi yang berupa narkotika dan psikotropika hanya dapat dilakukan berdasarkan resep dokter atau dokter gigi dan dilarang untuk disalahgunakan." Pekerjaan kefarmasian tersebut harus dilakukan oleh tenaga kesehatan yang mempunyai keahlian dan kewenangan sesuai dengan ketentuan peraturan perundang-undangan. Dalam hal ini 
tenaga kesehatan yang berwenang penuh untuk menyimpan dan menyerahkan narkotika dan psikotropika adalah apoteker.

b. Peraturan Pemerintah No. 51 Tahun 2009 tentang Pekerjaan Kefarmasian Pasal 1 ayat 1 disebutkan bahwa: "Pekerjaan Kefarmasian adalah pembuatan termasuk pengendalian mutu sediaan farmasi, pengamanan, pengadaan, penyimpanan dan pendistribusi atau penyaluran obat, pengelolaan obat, pelayanan obat atas resep dokter, pelayanan informasi obat, serta pengembangan obat, bahan obat dan obat tradisional." Menyimpan dan menyerahkan narkotika dan psikotropika merupakan salah satu bentuk pelayanan obat atas resep dokter. Selanjutnya, diperkuat lagi dengan Pasal 24 (c) yang menyatakan bahwa dalam melakukan pekerjaan kefarmasian pada fasilitas pelayanan kefarmasian, Apoteker dapat menyerahkan obat keras, narkotika dan psikotropika kepada masyarakat atas resep dari dokter sesuai dengan ketentuan peraturan perundang-undangan.

c. Undang-Undang No. 5 Tahun 1997 tentang Psikotropika

- Pasal 12 tentang penyaluran, ayat 2 (b):

“2. Penyaluran psikotropika sebagaimana dimaksud pada ayat 1 hanya dapat dilakukan oleh:

b. Pedagang besar farmasi kepada pedagang besar farmasi lainnya, apotek, sarana penyimpanan sediaan farmasi pemerintah, rumah sakit, dan lembaga penelitian dan/atau lembaga pendidikan."

- Pasal 14 tentang penyerahan, ayat 1, 2, 4, 5 dan 6:

“1. Penyerahan psikotropika dalam rangka peredaran sebagaimana dimaksud dalam pasal 8 hanya dapat dilakukan oleh apotek, rumah sakit, puskesmas, balai pengobatan, dan dokter.

2. Penyerahan psikotropika oleh apotek hanya dapat dilakukan kepada: apotek lainnya, rumah sakit, puskesmas, balai pengobatan, dokter, dan pengguna/pasien.

4. Penyerahan psikotropika oleh apotek, rumah sakit, puskesmas dan balai pengobatan sebagaimana dimaksud pada ayat (1) dilaksanakan berdasarkan resep dokter.

5. Penyerahan psikotropika oleh dokter sebagaimana dimaksud pada ayat (1), dilaksanakan dalam hal:

a. Menjalankan praktek terapi dan diberikan melalui suntikan

b. Menolong orang sakit dalam keadaan darurat

c. Menjalankan tugas di daerah terpencil yang tidak ada apotek.

6. Psikotropika yang diserahkan dokter sebagaimana dimaksud pada ayat (5) hanya dapat diperoleh dari apotek."

Menurut Undang-Undang Psikotropika, apotek merupakan salah satu sarana kesehatan tempat penyaluran dan penyerahan psikotropika berdasarkan resep dokter. Tenaga kesehatan yang berwenang mutlak untuk menyerahkan psikotropika berdasarkan resep dokter di apotek adalah apoteker.

d. Undang-Undang No. 35 Tahun 2009 tentang Narkotika

- Pasal 40 tentang Penyaluran Narkotika ayat 1 dan 2: 
“1. Industri Farmasi tertentu hanya dapat menyalurkan Narkotika kepada:

a. pedagang besar farmasi tertentu;

b. apotek;

c. sarana penyimpanan sediaan farmasi pemerintah tertentu; dan

d. rumah sakit.

2. Pedagang besar farmasi tertentu hanya dapat menyalurkan Narkotika kepada:

a. pedagang besar farmasi tertentu lainnya;

b. apotek;

c. sarana penyimpanan sediaan farmasi pemerintah tertentu;

d. rumah sakit; dan

e. lembaga ilmu pengetahuan."

- Pasal 43 tentang Penyerahan Narkotika:

“1. Penyerahan Narkotika hanya dapat dilakukan oleh:

a. apotek;

b. rumah sakit;

c. pusat kesehatan masyarakat;

d. balai pengobatan; dan

e. dokter.

2. Apotek hanya dapat menyerahkan Narkotika kepada:

a. rumah sakit;

b. pusat kesehatan masyarakat;

c. apotek lainnya;

d. balai pengobatan;

e. dokter; dan

f. pasien.

3. Rumah sakit, apotek, pusat kesehatan masyarakat, dan balai pengobatan hanya dapat menyerahkan Narkotika kepada pasien berdasarkan resep dokter.

4. Penyerahan Narkotika oleh dokter hanya dapat dilaksanakan untuk:

a. menjalankan praktik dokter dengan memberikan Narkotika melalui suntikan;

b.menolong orang sakit dalam keadaan darurat dengan memberikan Narkotika melalui suntikan; atau

c. menjalankan tugas di daerah terpencil yang tidak ada apotek.

5. Narkotika dalam bentuk suntikan dalam jumlah tertentu yang diserahkan oleh dokter sebagaimana dimaksud pada ayat (4) hanya dapat diperoleh di apotek."

Menurut Undang-Undang Narkotika, apotek merupakan salah satu sarana kesehatan tempat penyaluran dan penyerahan narkotika berdasarkan resep dokter. Tenaga kesehatan yang berwenang mutlak untuk menyerahkan narkotika berdasarkan resep dokter di apotek adalah apoteker.

3. Apotek Rakyat dapat merupakan 1 (satu) atau gabungan paling banyak 4 (empat) Pedagang Eceran Obat sesuai yang dinyatakan pada Pasal 4 ayat 2, selanjutnya pada Pasal 6 disebutkan bahwa Apotek Rakyat harus mempunyai 1 (satu) orang apoteker sebagai penanggung jawab dan dapat dibantu oleh asisten apoteker. Dalam hal ini berarti pelayanan yang diberikan apoteker tidak bisa optimal karena dalam waktu bersamaan tidak mungkin apoteker memberikan pelayanan pada tempat yang berbeda, sehingga peran aporeker dalam memberikan asuhan kefarmasian (Pharmaceutical Care) yang meliputi pemberian informasi, 
edukasi, konseling serta monitoring kepada pasien mengenai obat akan sulit atau bahkan tidak tercapai di Apotek Rakyat. Peraturan ini juga masih lemah karena tidak menegaskan bahwa apoteker harus ada jika apotek buka. Peraturan ini hanya mengatakan bahwa Apotek Rakyat harus memiliki apoteker, tetapi tidak menjelaskan keberadaan apoteker di apotek, apakah harus digantikan jika apoteker berhalangan hadir sebagaimana yang tercantum pada Keputusan Menteri Kesehatan No. 1332/MENKES/SK/X/2002 Pasal 19 ayat 1 dan 2, sebagai berikut:

“1. Apabila Apoteker Pengelola Apotek berhalangan melakukan tugasnya pada jam buka apotek. Apoteker Pengelola Apotek harus menunjuk Apoteker pendamping.

2. Apabila Apoteker Pengelola Apotek dan Apoteker pendamping karena hal-hal tertentu berhalangan melakukan tugasnya, Apoteker Pengelola Apotek menunjuk Apoteker pengganti."

Sehingga pasal ini semakin membuat ketidakjelasan tentang posisi profesi apoteker di Apotek Rakyat. Selain itu, peraturan ini juga tidak menjelaskan jam buka apotek, padahal Apotek Rakyat hanya memiliki 1 (satu) orang apoteker yang artinya jika apoteker berhalangan hadir dan tidak ada yang menggantikan, dapat menyebabkan pelayanan kefarmasian kepada masyarakat menjadi kurang optimal karena ketika apotek buka kemungkinan tidak ada apotekernya. Dalam hal ini berarti masyarakat dirugikan karena masyarakat tidak terlindungi dari pelayanan farmasi sesuai persyaratan mutu sehingga masyarakat akan terkena dampak dari bahaya yang disebabkan oleh penggunaan sediaan farmasi dan alat kesehatan yang tidak memenuhi persyaratan mutu, keamanan dan khasiat/kemanfaatan sebagai akibat dari tidak adanya tenaga kesehatan yang berwenang dan mempunyai keahlian atas pekerjaan kefarmasian tersebut. Selain itu, kedua pasal tersebut bertentangan dengan Peraturan Pemerintah No. 51 Tahun 2009 Pasal 51 ayat 1 yang menyatakan bahwa pelayanan kefarmasian di apotek hanya dapat dilakukan oleh apoteker dan pada pasal 54 ayat 1 bahwa apoteker hanya dapat melaksanakan praktek di 1 (satu) apotek saja.

Selain itu, tidak menutup kemungkinan apabila terjadi penjualan dan pembelian atau pengadaan obat secara ilegal dan adanya obat palsu (obat yang tidak memiliki nomor ijin registrasi) maupun obat kadaluarsa di Apotek Rakyat dikarenakan kurangnya pengawasan apoteker. Sedangkan apabila terjadi pelanggaran tersebut, dapat dikenakan tindakan pidana sebagaimana dalam:

a. Undang-Undang No. 8 Tahun 1999 tentang Perlindungan Konsumen Pasal 8 ayat 1a bahwa "Pelaku usaha dilarang memproduksi dan/atau memperdagangkan barang dan/atau jasa yang tidak memenuhi atau tidak sesuai dengan standar yang dipersyaratkan dan ketentuan peraturan perundang-undangan." Dan Pasal 62 ayat 1 bahwa Pelaku usaha yang melanggar dalam pasal 8, dipidana dengan pidana penjara paling lama 5 tahun atau pidana denda paling banyak Rp 2.000.000.000,00.

b. Undang-Undang Kesehatan No. 36 Tahun 2009 Pasal 196, yaitu:

"Setiap orang yang dengan sengaja memproduksi atau mengedarkan sediaan farmasi dan/atau alat kesehatan yang tidak memenuhi standar dan/atau persyaratan keamanan, khasiat atau kemanfaatan, dan mutu sebagaimana dimaksud dalam Pasal 98 ayat (2) dan ayat (3) dipidana dengan pidana penjara paling lama 10 (sepuluh) tahun dan denda paling banyak Rp 1.000.000.000,00 (satu miliar rupiah)." 
Kemudian Pasal 197:

"Setiap orang yang dengan sengaja memproduksi atau mengedarkan sediaan farmasi dan/atau alat kesehatan yang tidak memiliki izin edar sebagaimana dimaksud dalam Pasal 106 ayat (1) dipidana dengan pidana penjara paling lama 15 (lima belas) tahun dan denda paling banyak Rp 1.500.000.000,00 (satu miliar lima ratus juta rupiah).

Apabila terjadi hal-hal tersebut diatas, penulis berpendapat bahwa apoteker sangat dirugikan dengan kata lain apoteker dapat dijerat pidana karena dianggap sebagai penanggungjawab Apotek Rakyat. Sehingga ketentuan tentang Apotek Rakyat ini tidak memberikan perlindungan hukum bagi apoteker atas pekerjaan kefarmasian.

Kemudian, pada Pasal 9 dijelaskan mengenai sanksi bagi pelanggaran yang dilakukan oleh Apotek Rakyat, yaitu hanya dikenakan tindakan administratif. Sedangkan apabila Apotek Rakyat tersebut dijalankan oleh orang yang tidak mempunyai kewenangan dan keahlian atas pekerjaan kefarmasian dikarenakan dalam waktu bersamaan, apoteker tidak mungkin berada ditempat yang sama, maka ketentuan Apotek Rakyat ini bertentangan dengan UndangUndang Kesehatan No. 36 Tahun 2009 Pasal 198, yaitu:

"Setiap orang yang tidak memiliki keahlian dan kewenangan untuk melakukan praktik kefarmasian sebagaimana dimaksud dalam Pasal 108 dipidana dengan pidana denda paling banyak Rp100.000.000,00 (seratus juta rupiah)."

Selain itu, masyarakat sebagai penerima pelayanan kefarmasian menjadi tidak terlindungi akibat pengawasan yang kurang tersebut.

Seperti yang disampaikan oleh E. Uttrecht, beliau mengatakan bahwa menjamin kepastian oleh karena hukum adalah tugas dari hukum. Hukum yang berhasil menjamin banyak kepastian dalam hubungan-hubungan kemasyarakatan adalah hukum yang berguna. Kepastian dalam atau dari hokum tercapai apabila hukum itu (peraturan perundangundangan) didalamnya tidak terdapat keterangan-keterangan yang bertentangan dan tidak terdapat istilah-istilah yang dapat ditafsirkan secara berlainan. Sehingga setiap subjek hukum akan memperoleh akibat hukum yang dikehendaki dalam suatu peristiwa hukum tertentu dan terhindar dari tindakan sewenang-wenang.

Kemudian, Asas yang dipenuhi hukum menurut Fuller yang terdiri dari delapan asas (asas ini sudah diuraikan pada pembahasan asas kepastian hukum). Apabila tidak dipenuhi maka gagallah hukum disebut sebagai hukum. Beberapa asas yang disebutkan Fuller diantaranya adalah tidak boleh ada peraturan yang saling bertentangan dan harus ada kesesuaian antara peraturan dan pelaksanaan sehari-hari. Sedangkan berdasarkan uraian diatas, penulis menyimpulkan bahwa isi dari Peraturan Menteri Kesehatan No. 284/MENKES/PER/III/2007 tentang Apotek Rakyat tersebut bertentangan dan banyak terdapat ketidaksesuaian dengan ketentuan mengenai apotek pada umumnya sesuai dengan peraturan perundangan-undangan yang berlaku. Oleh karena itu, dapat disimpulkan bahwa hubungan antara kepastian hukum Apotek Rakyat dengan pekerjaan kefarmasian adalah bahwa ketentuan mengenai Apotek Rakyat tidak memberikan kepastian hukum bagi apoteker atas pekerjaan kefarmasian.

Dengan tercapainya kepastian hukum, subjek hukum akan memperoleh akibat hukum yang dikehendaki dalam suatu peristiwa hukum tertentu dan terhindar dari tindakan sewenang-wenang, dengan kata lain suatu kepastian hukum akan memberikan perlindungan hukum kepada subjek hukum. Kemudian, salah satu fungsi dari hukum tertulis (Peraturan Perundang-Undangan) adalah menjamin ketertiban dalam masyarakat. Ketertiban dalam masyarakat ini akan tercapai pula jika dalam suatu peraturan perundang-undangan mencerminkan dan sesuai dengan hakekat dari kepastian hukum. Tercapainya kepastian hukum juga akan memberikan keadilan bagi para pihak yang berkepentingan. Sehingga, 
apabila kepastian hukum tersebut tidak tercapai, maka hukum tersebut tidak dapat memberikan perlindungan, keadilan dan ketertiban bagi para pihak yang berkepentingan, yang dalam hal ini adalah masyarakat, baik masyarakat umum maupun masyarakat profesi (apoteker).

\section{KESIMPULAN DAN SARAN}

\section{A. KESIMPULAN} berikut:

Dari penjelasan dan pembahasan bab demi bab dapat diambil kesimpulan sebagai

1. Apotek menurut Peraturan Pemerintah No. 51 Tahun 2009 tentang Pekerjaan Kefarmasian adalah sarana pelayanan kefarmasian tempat dilakukan praktek kefarmasian oleh Apoteker.

2. Pekerjaan kefarmasian menurut:

a. Undang-Undang Kesehatan No. 36 Tahun 2009 adalah pembuatan termasuk pengendalian mutu sediaan farmasi, pengamanan, pengadaan, penyimpanan dan pendistribusian obat, pelayanan obat atas resep dokter, pelayanan informasi obat serta pengembangan obat, bahan obat dan obat tradisional yang harus dilakukan oleh tenaga kesehatan yang mempunyai keahlian dan kewenangan sesuai dengan ketentuan peraturan perundang-undangan.

b. Peraturan Pemerintah No. 51 Tahun 2009 tentang Pekerjaan Kefarmasian adalah Pembuatan termasuk pengendalian mutu sediaan farmasi, pengamanan, pengadaan, penyimpanan dan pendistribusi atau penyaluran obat, pengelolaan obat, pelayanan obat atas resep dokter, pelayanan informasi obat, bahan obat dan obat tradisional.

Tenaga kesehatan yang mempunyai keahlian dan kewenangan dalam pekerjaan kefarmasian tersebut adalah apoteker. Apoteker hanya dapat melaksanakan pekerjaan kefarmasian di 1 (satu) apotek. Sehingga pengawasan terhadap seluruh kegiatan pekerjaan kefarmasian dapat terawasi dengan baik. Dalam melakukan pekerjaan kefarmasian di apotek, apoteker dapat meracik obat, menyerahkan obat keras, narkotika dan psikotropika kepada masyarakat atas resep dari dokter sesuai peraturan perundangundangan.

3. Apotek Rakyat menurut Peraturan Menteri Kesehatan No. 284/MENKES/PER/III/2007 adalah sarana kesehatan tempat dilaksanakannya pelayanan kefarmasian dimana dilakukan penyerahan obat dan perbekalan kesehatan dan tidak melakukan peracikan, serta dilarang menyediakan dan menyerahkan narkotika dan psikotropika. Apotek rakyat merupakan 1 (satu) atau gabungan dari paling banyak 4 (empat) Pedagang Eceran Obat. Setiap Apotek Rakyat harus memiliki 1 (satu) orang Apoteker sebagai penanggung jawab. Sehingga pengawasan terhadap seluruh kegiatan pekerjaan kefarmasian tidak dapat terawasi dengan baik mengingat 1 (satu) orang apoteker tidak dapat mengawasi 4 (empat) tempat berbeda pada waktu yang sama.

Hal tersebut bertentangan dengan Undang-Undang Kesehatan No. 36 Tahun 2009 dan Peraturan Pemerintah No. 51 Tahun 2009 tentang Pekerjaan Kefarmasian, sehingga Peraturan Menteri Kesehatan No. 284/MENKES/PER/III/2007 tentang Apotek Rakyat tidak memberikan kepastian hukum bagi apoteker dalam menjalankan tugas keprofesiannya atas pekerjaan kefarmasian. 
4. Dengan tercapainya kepastian hukum, subjek hukum akan memperoleh akibat hukum yang dikehendaki dalam suatu peristiwa hukum tertentu dan terhindar dari tindakan sewenang-wenang, dengan kata lain suatu kepastian hukum akan memberikan perlindungan hukum kepada subjek hukum. Kemudian, tercapainya kepastian hukum juga akan memberikan keadilan dan ketertiban bagi subjek hukum. Sehingga, apabila Peraturan Menteri Kesehatan No. 284/MENKES/PER/III/2007 tentang Apotek Rakyat tidak memberikan kepastian hukum bagi apoteker dalam menjalankan tugas keprofesiannya atas pekerjaan kefarmasian, maka Peraturan Menteri Kesehatan No. 284/MENKES/PER/III/2007 tidak dapat memberikan perlindungan hukum, keadilan dan ketertiban bagi subjek hukum, yang dalam hal ini adalah masyarakat, baik masyarakat umum maupun masyarakat profesi (apoteker) atas pekerjaan kefarmasian.

\section{B. SARAN}

Karena ketentuan mengenai Apotek Rakyat berdasarkan Peraturan Menteri Kesehatan No. 284/MENKES/PER/III/2007 bertentangan atau tidak sesuai dengan ketentuan pekerjaan kefarmasian menurut Undang-Undang Kesehatan No. 36 Tahun 2009 dan Peraturan Pemerintah No. 51 Tahun 2009 sehingga Peraturan Menteri Kesehatan tersebut tidak dapat memberikan kepastian hukum bagi apoteker dalam melaksanakan tugas keprofesiannya atas pekerjaan kefarmasian, maka penulis menyarankan Peraturan Menteri Kesehatan No. 284/MENKES/PER/III/2007 tentang Apotek Rakyat harus dicabut, untuk selanjutnya hanya mengacu pada ketentuan apotek sesuai peraturan perundang-undangan yang berlaku.

Permohonan pencabutan Peraturan Menteri tersebut diajukan kepada Mahkamah Konstitusi melalui uji materiil sebagai berikut:

1. Ketentuan Apotek Rakyat mengenai tidak diperbolehkannya peracikan obat dan penyerahan narkotika dan psikotropika merugikan masyarakat karena hak masyarakat untuk mendapatkan pelayanan kefarmasian yang utuh dilanggar. Selain itu, kewenangan profesi apoteker atas pekerjaan kefarmasian terlanggar juga.

2. Pengawasan terhadap pekerjaan kefarmasian di Apotek Rakyat tidak terlaksana dengan baik karena keberadaan 1 (satu) orang apoteker untuk mengawasi maksimal 4 (empat) tempat yang berbeda, sehingga memungkinkan terjadinya pelanggaran di Apotek Rakyat. Hal tersebut menyebabkan masyarakat menjadi tidak terlindungi dari pelanggaran tersebut. Selain itu, kewenangan profesi apoteker berdasarkan kode etik profesi untuk dapat memberikan pelayanan kefarmasian sesuai dengan persyaratan mutu yang baik kepada pasien terlanggar juga.

\section{DAFTAR PUSTAKA}

, 1999, Kamus Besar Bahasa Indonesia, Edisi kesepuluh, Departemen Pendidikan dan Kebudayaan, Jakarta: Balai Pustaka.

, 2007, Pedoman Cara Distribusi Obat Yang Baik, Cetakan ketiga, Jakarta: Badan POM.

1998, Penyusunan Kamus Hukum Umum Bahasa Belanda Bahasa Indonesia, Jakarta: BPHN Departemen Kehakiman dan HAM RI. 
A. Sonny Keraf \& Mikhael Dua, 2001, Ilmu Pengetahuan (Sebuah Tinjauan Filosofis), Yogyakarta: Kanisius.

Achmad Ali, 1996, Menguak Tabir Hukum: Suatu Kajian Filosofis dan Sosiologis, Jakarta: Chandra Pratama.

Abdulkadir Muhamad, 2000, Hukum Perdata Indonesia, Bandung: PT Citra Aditya Bakti.

Amir Syarif et all, 1989, Farmakologi dan Terapi, Edisi ketiga, Jakarta: Gaya Baru.

Anny Isfandyarie, 2006, Tanggung Jawab Hukum Dan Sanksi Bagi Dokter Buku I, Jakarta: Prestasi Pustaka.

Anonim, 2007, Pemerintah Resmikan Program Apotek Rakyat, Jakarta: Harian Umum Kompas.

Budiono Kusumohamidjojo, 2004, Filsafat Hukum: Problema Ketertiban yang Adil, Jakarta: Grasindo.

Charles J.P. Siregar, 2004, Farmasi Klinik Teori dan Penerapan, Cetakan kesatu, Jakarta: Penerbit Buku Kedokteran EGC.

CST Kansil, 1984, Pengantar Ilmu Hukum \& Tata Hukum Indonesia, Jakarta: Balai Pustaka.

Darji Darmodiharjo, Shidarta, 1996, Penjabaran Nilai-nilai Pancasila dalam Sistem Hukum Indonesia, Jakarta: Rajawali Pers.

E. Utrecht, 1989, Pengantar dalam Hukum Indonesia, disadur dan direvisi oleh Moh. Saleh Djindang, Cetakan Kesebelas, Jakarta: Sinar Harapan.

Elin Yulinah Sukandar, Tren Dan Paradigma Dunia Farmasi, Bandung: Departemen Farmasi FMIPA ITB.

Ernst Mutchler, 1991, Dinamika Obat, Edisi kelima, Bandung: ITB.

Franz Magnis Suseno, 2001, Etika Politik, Jakarta: Gramedia Pustaka Utama.

Handy Sobandi, 2006, Cita Hukum dalam Pembebanan Benda pada Lembaga Jaminan Fudicia, Bandung: Thesis Program Studi Magister Ilmu Hukum Universitas Katolik Parahyangan.

Hilman Hadikusuma, 1995, Metode Pembuatan Kertas Kerja atau Skripsi Ilmu Hukum, Bandung: Mandar Maju.

Howard C. Ansel, 2005, Pengantar Bentuk Sediaan Farmasi diterjemahkan oleh : Farida Ibrahim, Edisi keempat, Jakarta: Universitas Indonesia Press.

Lufti Efendi, 2004, Pokok Pokok Hukum Administrasi, Cetakan ketiga, Malang: Bayumedia Publishing.

Melanie J. Rantucci, 2007, Komunikasi Apoteker-Pasien Panduan Konseling Pasien, Edisi Kedua, Jakarta: Penerbit Buku Kedokteran EGC.

Mohammad Anief, 2005, Manajemen Farmasi, Cetakan keempat, Yogyakarta: Gadjah Mada University Press.

Mohammad Anief, 2007, Farmasetika, Cetakan keempat, Yogyakarta: Gadjah Mada University Press.

Mohammad Nazir, 1985, Metode Penelitian, Jakarta: Ghalia Indonesia.

Muhamad Firmansyah, 2009, Tata Cara Mengurus Perizinan Usaha Farmasi \& Kesehatan, Cetakan pertama, Jakarta: Visimedia.

N.E. Algra, H.R.W. Gokkel, 1983, Kamus Istilah Hukum Fockema Andreae (Belanda-Indonesia), diterjemahan oleh: Saleh Adiwinata et. al., Bandung: Binacipta. 
Ridwan H.R., 2006, Hukum Adminstrasi Negara, Edisi kedua, Jakarta: Rajagrafindo Persada.

Rizki Prasa, 2009, Apotek Rakyat dan Apotek Waralaba, Surakarta: http://prastzadubidudam.blogspot.com.

S. Prayudi Atmosudirjo, 1994, Hukum Administrasi Negara, Cetakan kesepuluh, Jakarta: Ghalia Indonesia.

Sedarmayanti \& Syarifudin Hidayat, 2002, Metodologi Penelitian, Bandung: Mandar Maju.

Satjipto Rahardjo, 2006, Ilmu Hukum, Bandung: Citra Aditya Bakti.

Satjipto Rahardjo, 2006, Hukum Dalam Jagat Ketertiban, Jakarta: UKI Press.

Sidharta, 2006, Moralitas Profesi Hukum: Suatu Tawaran Kerangka Berpikir, Bandung: Rafika Aditama.

SF Marbun, 2003, Peradilan Administrasi Negara Dan Upaya Administratif Di Indonesia, Yogyakarta: UII Press Yogyakarta.

Soerjono Soekanto \& Sri Mamudji, 2001, Penelitian Hukum Normatif (Suatu Tinjauan Singkat), Jakarta: Rajawali Pers.

Sudikno Mertokusumo, 1993, Bab-bab tentang Penemuan Hukum, Bandung: Citra Aditya Bakti.

V. Nuraini Widjayanti, 2002, Obat-Obatan, Cetakan kesepuluh, Yogyakarta: Kanisius.

Veronica Komalawati, Peranan Informed Consent dalam Transaksi Terapeutik: Persetujuan dalam Hubungan Dokter dan Pasien, Bandung : Citra Aditya Bakti.

Wila Chandrawila Supriadi, 2006, Metode Penelitian (tidak dipublikasikan) dalam Materi Kuliah “Metode Penelitian Hukum”, Semarang: Program Pascasarjana Program Studi Magister Hukum Kesehatan Unika Soegijapranata.

Yustina Sri Hartini, 2010, Apotek Ulasan Beserta Naskah Peraturan Perundang-undangan Terkait Apotek Termasuk Naskah dan Ulasan Permenkes Tentang Apotek Rakyat, Edisi Revisi, Cetakan ketiga, Yogyakarta: Universitas Sanata Dharma.

\section{Perundang-undangan}

Undang-Undang Nomor 36 Tahun 2009 tentang Kesehatan.

Undang-Undang Nomor 35 Tahun 2009 tentang Narkotika.

Undang-Undang Nomor 8 Tahun 1999 tentang Perlindungan Konsumen.

Undang-Undang Nomor 5 Tahun 1997 tentang Psikotropika.

Peraturan Pemerintah Nomor 51 Tahun 2009 tentang Pekerjaan Kefarmasian.

Peraturan Menteri Kesehatan Nomor 922/MENKES/PER/X/1993 tentang Ketentuan dan Tata Cara Pemberian Izin Apotek.

Peraturan Menteri Kesehatan Nomor 284 Tahun 2007 tentang Apotek Rakyat.

Keputusan Menteri Kesehatan Nomor 1027/MENKES/SK/IX/2004 tentang Standar Pelayanan Kefarmasian di Apotek.

Keputusan Menteri Kesehatan Nomor 1332/MENKES/SK/X/2002 tentang Perubahan Atas Peraturan Menteri Kesehatan Nomor 922/MENKES/PER/X/1993 tentang Ketentuan dan Tata Cara Pemberian Izin Apotek. 